\title{
PEMANFAATAN LIMBAH SERBUK GERGAJI SEBAGAI MEDIA BUDIDAYA JAMUR TIRAM (Pleourotus ostreatus L.)
}

\author{
Hadi Susilo1a, Riki Rikardo¹, Suyamto ${ }^{1}$
}

\begin{abstract}
The development of the agricultural sector is not only food crops, but also plantation crops and horticulture. One of horticulture crops that have contributed to human is oyster mushroom. Oyster mushroom is highly suitable for people of Indonesia that is still difficult to meet the needs complete nutrition, especially protein needs. Contains essential amino acids: arginine, histidine, isoleucine, lysine, methionine, phenylalanine, threonine, tryptophan, valine, unsaturated fats, vitamin B1, B2, niacin, biotin, micro and macro elements. The oyster mushroom is also shown to be potent inhibitors of HIV-AIDS, cholesterol, blood sugar and cancer. Mushroom cultivation media requires for growth. In this study utilizes waste sawdust which there are many in the community with the goal of increasing the economic value and the standard of life. Cultivation starts from media preparation, sterilization, filling and incubation seed to harvest. Wet harvest oyster mushrooms for 5 weeks increased gradually. 1000 new baglogs, 750 baglogs already can produce 290 kilograms of harvested oyster mushrooms wet. The selling price is $\mathrm{Rp}$ 9,000 and total revenue is Rp 2.61 million for one month. Mushroom cultivation should be accompanied by the processing of waste in order to have a double added value of improving economic value and overcome the environment. Based on the data and the results of the discussion showed that the oyster mushroom cultivation can work well and provide benefits, so as to improve the economy for the community.
\end{abstract}

Keywords: Agriculture Waste, Oyster Mushrooms, Sawdust.

JURNAL PENGABDIAN PADA MASYARAKAT

Website: http://ojs.ejournal.id/index.php/ppm

Permalink: http://ojs.ejournal.id/index.php/ppm/article/view/105

How to cite (APA): Susilo, H., Rikardo, R., \& Suyamto. (2017). Pemanfaatan Limbah Serbuk Gergaji Sebagai Media Budidaya Jamur Tiram (Pleourotus ostreatus L.). Jurnal Pengabdian Pada Masyarakat, 2(1), 51-56.

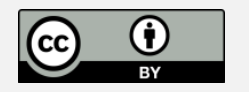

This is an open access article distributed under the terms of the Creative Commons Attribution 4.0 International License, which permits unrestricted use, distribution, and reproduction in any medium, provided the original work is properly cited.

\section{PENDAHULUAN}

Sektor pertanian di Indonesia merupakan sektor penting dalam pertumbuhan ekonomi nasional. Sebagian besar penduduk Indonesia tinggal di pedesaan dan lebih dari setengah jumlah penduduknya menggantungkan hidup pada sector pertanian. Perkembangan sektor pertanian tidak hanya komoditas tanaman pangan, tetapi juga tanaman perkebunan dan holtikultura. Kegiatan pertanian khususnya holtikultura

\footnotetext{
${ }^{1}$ Departemen Biologi Fakultas Sains dan Farmasi Universitas Mathla'ul Anwar Banten.

a hadisusilo1973@gmail.com
} 
terbagi menjadi empat golongan yaitu tanaman buah-buahan, tanaman sayuran, tanaman obat, dan tanaman bunga yang semakin banyak diminati petani karena mampu memberikan keuntungan yang lebih tinggi dibandingkan dengan tanaman palawija pada areal yang sama.

produk holtikultura memberi manfaat bagi manusia, diantaranya sebagai sumber pangan dan gizi, pendapatan keluarga, sedangkan bagi lingkungan adalah rasa estetikanya. Salah satunya yang mempunyai kontribusi terhadap manusia adalah jamur. Jamur sangat cocok untuk masyarakat Indonesia yang masih sulit dalam memenuhi kebutuhan gizi yang lengkap terutama kebutuhan akan protein. Sebagian besar masyarakat Indonesia belum banyak mengkonsumsi daging akibat tingkat kesejahteraan yang masih rendah. Asupan protein lebih banyak diperoleh dari pangan nabati, terutama dari berbagai jenis kacang-kacangan.

Jamur tiram atau dalam bahasa latin disebut Pleurotus sp. Merupakan salah satu jamur konsumsi yang bernilai tingi. Beberapa jenis jamur tiram yang biasa dibudidayakan oleh masyarakat Indonesia yaitu jamur tiram putih (P.ostreatus), jamur tiram merah muda P.flabellatus), jamur tiram abuabu (P. sajor caju), dan jamur tiram abalone (P.cystidiosus). Pada dasarnya semua jenis jamur ini memiliki karateristik yang hampir sama terutama dari segi morfologi, tetapi secara kasar, warna tubuh buah dapat dibedakan antara jenis yang satu dengan dengan yang lain terutama dalam keadaan segar.

Permintaan jamur yang standar di pasaran, karena jamur sebagai jenis sayuran yang banyak dikonsumsi oleh masyarakat, cita rasa yang lezat, bergizi tinggi dan bisa digunakan sebagai makanan alternatif untuk pengobatan. Mengandung 9 jenis dari 10 asam amino essensial: arginin, histidin, isoleusin, lisin, metionin, fenilalanin, treonin, triptofan, dan valin, serta $72 \%$ lemaknya tidak jenuh, vitamin B1 (thiamin), B2 (riboflavin), niasin dan biotin. elemen makro, antara lain $\mathrm{K}, \mathrm{P}, \mathrm{Ca}, \mathrm{Na}$, \& Mg. elemen mikro seperti $\mathrm{Cu}, \mathrm{Zn}$ dan lain-lain. Jamur juga terbukti ampuh untuk menghambat HIV-AIDS, kolesterol, gula darah dan juga kanker.

Tujuan dari pemanfaatan serbuk gergaji dalam budidaya jamur tiram ini diharapkan dapat menjadi informasi yang sangat berharga terhadap peningkatan nilai ekonomis dengan pemanfaatan limbah menjadi suatu yang lebih berguna dalam peningkatan taraf kehidupan masyarakat. Berdasarkan latar belakang yang ada pemanfaatan serbuk gergaji dalam budidaya jamur tiram memiliki tujuan terhadap peningkatan nilai ekonomis dengan pemanfaatan limbah gergaji yang banyak terdapat dimasyarakat 
dan tidak termanfaatkan menjadi suatu yang lebih berguna dalam peningkatan taraf kehidupannya.

\section{METODE PELAKSANAAN}

\section{Metode}

Kegiatan pengabdian ini menggunakan metode praktik, diskusi, dan pendampingan. Praktik, meliputi pembuatan rumah jamur, pembuatan medium tanam jamur, sterilisasi, pengisian bibit dan inkubasi. Diskusi dan tanya jawab, dilakukan pada waktu pemberian materi sebagai pengantar,dalam praktik maupun pada waktu pendampingan. Pendampingan dilakukan terutama pada saat pembuatan rumah jamur, pemeliharaan dan saat panen.

\section{Bahan}

Bahan yang dibutuhkan dalam pembuatan rumah jamur adalah anyaman bambu, genting, kayu, paralon ukuran diameter $10 \mathrm{~cm}$ (sesuai kebutuhan untuk tiang penyangga), semen, paku, dan plastik.Alat-yang diguna kan meliputi alat-alat pertukangan. Pembuatan media tanam jamur dan sterilisasi, meliputi pencampuran bahan, pengomposan, pengemasan, dan sterilisasi. Bahan-bahan yang diperlukan meliputi serbuk gergaji yang telah diayak (85-90\%), bekatul (10- 15\%) $\mathrm{CaCO}_{3}(1-2 \%)$ atau dengan perbandingan bahan serbuk gergaji: bekatul: kapur yaitu 100: 10-15:1, polybag ukuran $20 \times 35 \mathrm{~cm}$, kapas, cincin plastik, air dan sedikit gips sebagai campuran. Alat-alat yang dibutuhkan pada pembuatan media steril adalah, skop, autoklaf atau alat pengukus. Pengisian bibit kedalam media tanam diperlukan bibit jamur tiram F3, kapas dan cincin plastik; sedangkan alatnya antara lain skalpel/pinset steril.

\section{Cara Kerja}

\section{Pembuatan Rumah Jamur}

Rumah jamur yang dibuat berukuran $5 \times 10$ meter. Beberapa hal yang harus dipertimbangkan sebelum membuat rumah jamur adalah menentukan lokasi dan ukuran rumah jamur. Setelah ditentukan lokasi pembuatan rumah dapat dimulai dan pertama-tama menyiapkan material/bahan dan peralatan yang dibutuhkan, seperti anyaman bambu, bambu, kayu, kawat, paku, plastik dan alat-alat pertukangan. Mengukur lahan pada lokasi yang ditentukan, yaitu 5×10 meter. Kerangka rumah jamur dibuat dengan tiang pralon yang diisi semen dan disambung kayu, atap genting. Setelah kerangka jadi, dipasang genting dari tanah liat, dinding dari anyaman 
bambu yang di bagian bawah dilapisi plastik, dan dilengkapi jendela, pintu untuk keluar masuk. Rumah jamur setelah jadi, dilakukan sterilisasi dengan menaburkan kapur tohor dan insektisida, dan dibiarkan 1-2 hari.

Pembuatan Media, Sterilisasi, Pengisian Bibit dan Inkubasi

Rumah jamur setelah selesai dan disterilisasi, dilanjutkan pembuatan media steril, inokulasi bibit, inkubasi dan panen. Ada dua kegiatan utama dalam budidaya jamur tiram, yaitu pembuat media tanam dan menginokulasikan bibit jamur ke dalam media tanam tersebut serta menumbuhkan miselium tersebut menjadi badan buah. Gambar 1 adalah alur pembuatan media, sterilisasi, inokulasi, inkubasi hingga panen.

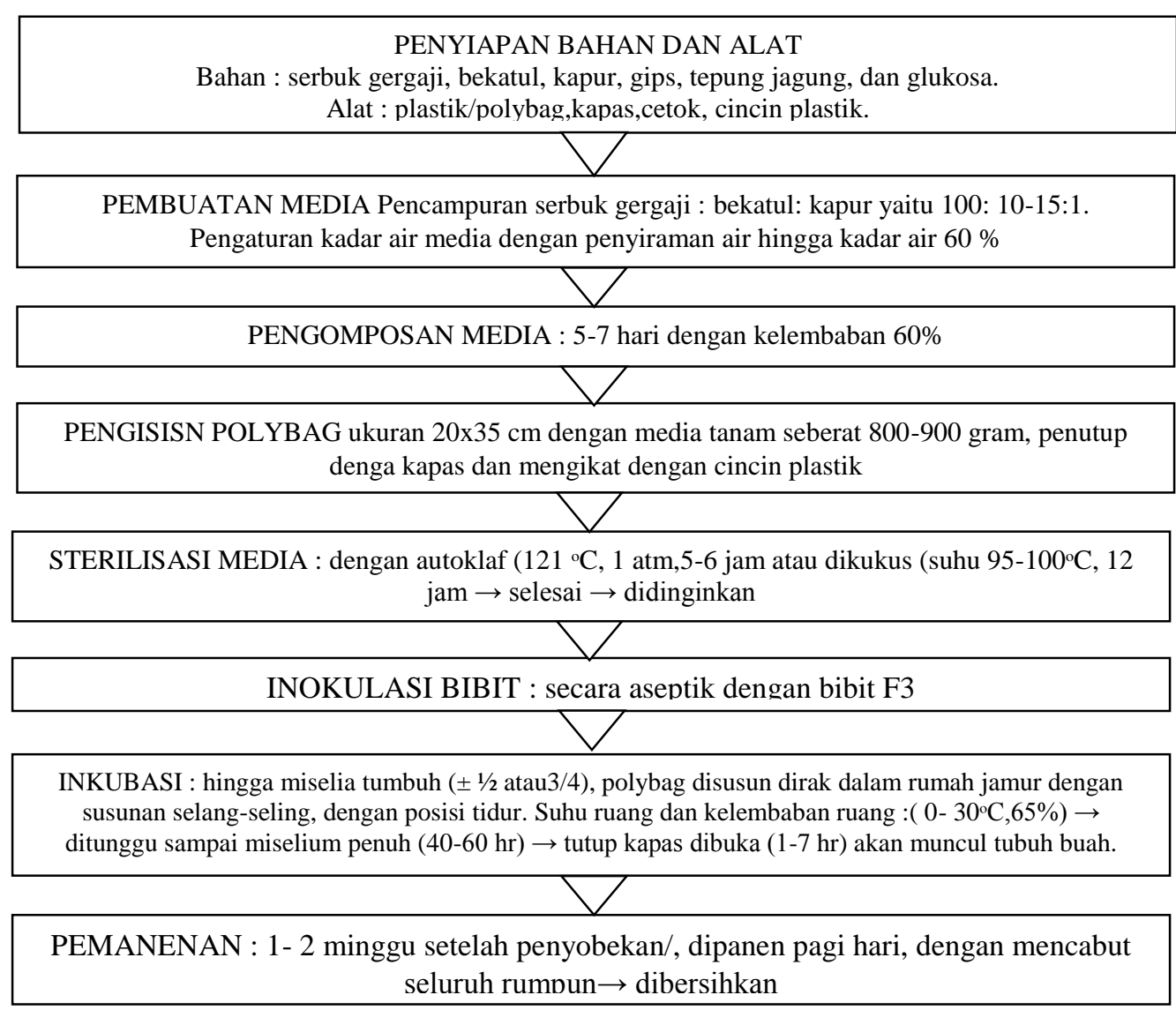

Gambar 1. Alur pembuatan media, sterilisasi, inokulasi, inkubasi, dan panen

\section{HASIL DAN PEMBAHASAN}

Proses budidaya jamur tiram dimulai dengan membuat 1000 baglog. Baglog merupakan media tanam tempat meletakkan bibit jamur tiram. Bahan utama baglog adalah serbuk gergaji, karena jamur tiram termasuk 
jamur kayu. Baglog dibungkus plastik berbentuk silinder, dimana salah satu ujungnya diberi lubang. Pada lubang tersebut jamur tiram akan tumbuh menyembul keluar. Proses sterilisasi merupakan proses yang penting namun terkendala dengan belum tersedianya autoklaf. Mengatasi hal tersebut dapat menggunakan drum bekas.

Permukaan baglog yang telah tertutup sempurna dengan miselium, biasanya dalam 1-2 minggu, jamur akan tumbuh dan sudah bisa dipanen. Setelah itu baglog dibuang atau bisa dijadikan bahan kompos. Panen jamur tiram basah selama 5 minggu (35 hari) meningkat secara bertahap. Pembuatan dari 1000 baglog, terdapat 750 baglog yang sudah dapat dipanen. Sebanyak 750 polybag, secara akumulatif menghasilkan 290 kilogram jamur tiram basah. Baglog jamur bisa dipanen 5-8 kali, bila perawatannya baik. Baglog yang memiliki bobot sekitar $1 \mathrm{~kg}$ akan menghasilkan jamur sebanyak 0,6-0,8 kg. Perubahan rata-rata hasil panen setiap minggu (Tabel 1).

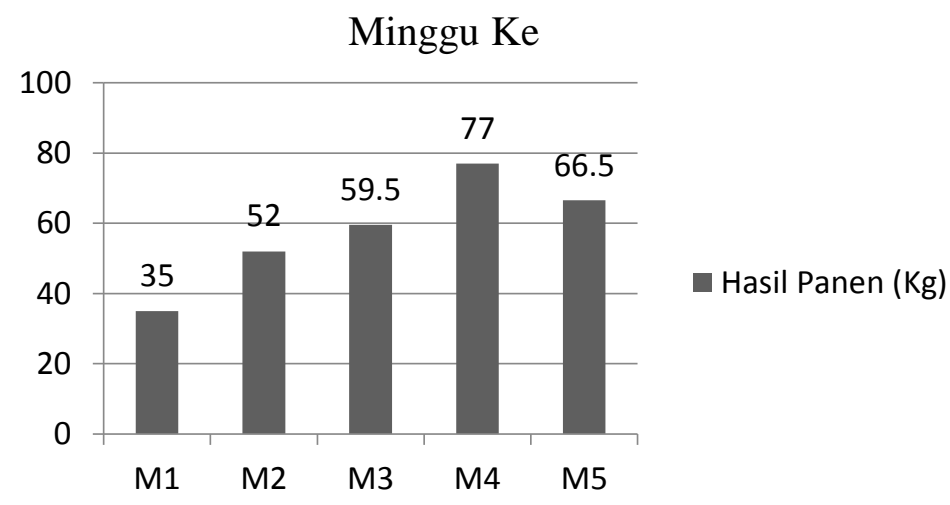

Tabel 1. Perubahan Rata-rata Hasil Panen Disetiap Minggu

Berdasarkan Tabel 1 dapat dilihat produksi jamur dalam satu bulan dengan harga jual sebesar Rp 9.000 dan total penerimaan dari hasil penjualan jamur tiram selama satu bulan adalah sebesar Rp 2.610.000. Pendapatan usaha jamur tiram merupakan selisih penerimaan dengan keseluruhan biaya yang dikeluarkan, besarnya pendapatan dari usaha jamur tiram. Panen dilakukan sebanyak 5 kali. Pemasaran dilakukan kepada masyarakat dan pasar tradisional sekitar. Berdasarkan hal tersebut budidaya jamur tiram dapat meningkatkan ekonomi masyarakat juga pemenuhan gizi keluarga.

Hama dan penyakit utama pada jamur tiram adalah tikus, dapat dikendalikan dengan menggunakan seng sebagai pembatas bangunan 
kubung agar tidak naik keatas atau lem tikus. Pada malam hari sering dilakukan pengecekan kubung untuk mengusir tikus. Tungau/kutu juga dapat merusak media dan mempengaruhi pertumbuhan jamur, sehingga media yang terserang tungau sebaiknya segera dibuang jauh-jauh. Serangan jamur Trichoderma sp. tampak tidak terjadi dalam media tanam, sehingga media cukup steril.

Agar usaha ini tidak menghasilkan limbah, maka limbah media tanam jamur dapat ditingkatkan nilai ekonominya menjadi kompos, yang dapat memberikan alternatif usaha tambahan dari budidaya jamur tiram. Tambahan dari hasil penjualan kompos dari limbah media tanam jamur, perkilogram kompos dapat dijual sekitar Rp 2.000,-. Budidaya jamur perlu disertai dengan pengolahan limbahnya agar memiliki nilai tambah ganda yaitu meningkatkan nilai ekonomi dan mengatasi lingkungan.

\section{SIMPULAN}

Hasil pembahasan menunjukkan bahwa budidaya jamur tiram menggunakan media limbah gergaji dapat berhasil dengan baik dan memberikan keuntungan, sehingga dimungkinkan dapat meningkatkan ekonomi bagi masyarakat.

\section{REFERENSI}

Abdisobar, R., Bakar, A., \& Yuniar. (2014). Analisis kelayakan usaha budidaya jamur tiram di desa cilame ciwidey kabupaten bandung. Reka Integra, 1(2), 168-179.

Hedi, H. (2010). Teknologi budidaya jamur tiram putih (Pleurotus ostreatus). Jambi: BPTP.

Islami, A. Setyo, A. P., \& Sukesi. (2013). Pengaruh komposisi ampas tebu dan kayu sengon sebagai media pertumbuhan terhadap nutrisi jamur tiram (Pleurotus ostreatus). Jurnal Sains dan Seni Pomits, 2(1), 1-4.

Susilawati \& Raharjo, B. (2010). Budidaya jamur tiram (Pleourotus ostreatus var florida) yang ramah lingkungan. Palembang: BPTP Sumatera Selatan.

Umniyatie, S., Astuti, Priamadi, D., \& Henuhili, V. (2013). Budidaya jamur tiram (Pleuretus.Sp) sebagai alternatif usaha bagi masyarakat korban erupsi Merapi di Dusun Pandan, Wukirsari, Cangkringan, Sleman DIY. Inotek 17(2), 162-175. 